\title{
RFLP for the human erb-A1 gene
}

S.H.Rider, C.J.Bailey, R.Voss, D.Sheer, L.R.Hiorns and E.Solomon

Imperial Cancer Research Fund, Lincoln's Inn Fields, London WC2A 3PX, UK

SOURCE / DESCRIPTION : $2.9 \mathrm{~Kb}$. ECORI / HindIII fragment subcloned from the original HE-A1 clone that was specific for $\mathrm{V}$-erb-A sequences. (Jansson et.al. 1983).

POLYMORPHISM: PvUII identifies two alleles with bands at $2.0 \mathrm{~Kb} .(\mathrm{A} 1$ ) and $1.2 ; 0.8 \mathrm{~Kb} .(\mathrm{A} 2)$.

FREQUENCY : A1 2.0 Kb. 0.11

A2 $\quad 1.2 ; 0.8 \mathrm{~Kb}$. 0.89

NOT POLYMORPHIC FOR : BamHI, ECORI, HindIII, HinfI, KpnI, PstI, TaqI

CHROMOSOMAL LOCALIZATION : Human erb-A1 gene has been mapped to chromosome 17 (17q12-q21). (Sheer et.al.,1985).

MENDELIAN INHERITANCE : Allelic segregation was demonstrated for the PvuII polymorphism in two families.

Somatic cell hybrids were also constructed between mouse cells and cells from an individual who was heterozygous (A1/A2) for the PvuII polymorphism. One hybrid containing a normal chromosome 17 as the only human component showed only the A1 allele.

PROBE AVAILABILITY : The probe was obtained on request from B.Vennstrom, EMBL; Heidelberg.

OTHER COMMENTS : An invariant band at $1.0 \mathrm{~Kb}$. was also detected with this probe.

REFERENCE : Jansson,M.,Philipson,L.and Vennstrom,B. (1983) EMBO J. 2 561-565. Sheer,D.et.al., (1985) Ann. Hum. Genet.49 167-171.

ACKNOWLEDGEMENTS : We thank B.Vennstrom for supplying the human erb-A1 probe.

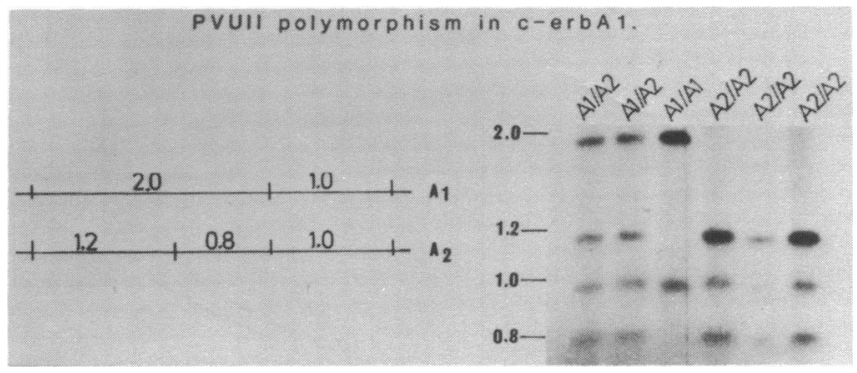

